\title{
KAJIAN YURIDIS TERHADAP PERBUATAN PIDANA YANG DILAKUKAN OLEH GENG MOTOR MENURUT HUKUM PIDANA INDONESIA
}

\author{
Oleh : \\ Sri Winugroho* \\ Suzanalisa* \\ Amir Syarifuddin *
}

\begin{abstract}
ABSTRAK
Fenomena yang terjadi saat ini adalah bahwa tingkat kejahatan jalanan di hampir seluruh kota besar di Indonesia, mengalami perubahan pada strata pelaku. Kejahatan jalanan yang dulunya didominasi oleh kelompok-kelompok penjahat kambuhan, kini justru didominasi oleh kelompok baru dari kalangan pelajar dan bekas pelajar yang menganggur. Mereka bermutasi menjadi gerombolan geng motor. dampak buruk dari kegiatan geng motor terhadap keamanan, ketertiban dan ketentraman di tengah masyarakat. Pada sisi lain, rentetan kejadian keganasan dan kebrutalan kelompok geng motor, semakin menggugah kesadaran bersama betapa perlunya dilakukan penegakan hukum yang keras dan bersifat komprehensif terhadap pelaku, sedemikian sehingga kegiatan kelompok jalanan tersebut bisa diberantas, dan korban-korban tidak lagi berjatuhan. Dalam perspektif perundang-undangan Indonesia, terhadap pelaku kejahatan jalanan yang dilakukan secara bersama-sama, dapat dikenakan ketentuan pidana sebagaimana termaktub di dalam Kitab Undang-Undang Hukum Pidana (KUHP), dan ketentuan pidana khusus seperti pidana yang berkaitan dengan lalu lintas sebagaimana diatur di dalam Undang-Undang Nomor 22 Tahun 2009 tentang Lalu Lintas dan Angkutan Jalan (selanjutnya disebut Undang-Undang Lalu Lintas dan Angkutan Jalan), atau ketentuan pidana yang berhubungan dengan narkotika sebagaimana diatur di dalam Undang-Undang Nomor 35 Tahun 2009 tentang narkotika (selanjutnya disebut Undang-Undang Narkotika).
\end{abstract}

Kata Kunci: Geng Motor, Hukum Pidana Indonesia

\section{A. Latar Belakang Masalah}

Dinamika tindak pidana yang terjadi di tengah masyarakat, setidaknya dapat dilihat pada 2 (dua) hal yakni munculnya bentuk-bentuk kejahatan baru dan semakin meningkatnya angka kriminalitas yang bersifat konvensional. Seiring dengan arus globalisasi, yang ditandai dengan pesatnya perkembangan ilmu pengetahuan dan teknologi terutama teknologi informasi dan komunikasi, telah melahirkan bentuk-bentuk kejahatan baru yang kompleks, bersifat transnasional dan teroganisir dengan dukungan manajemen yang profesional dan teknologi yang canggih.

\footnotetext{
* Wakapolresta Jambi, Alumni Program Magister Ilmu Hukum Unbari.

* Pengajar Program Magister Ilmu Hukum Unbari.

* Pengajar Program Magister Ilmu Hukum Unbari.
} 
Untuk mengantisipasi munculnya berbagai bentuk dan modus tindak pidana yang baru tersebut, maka lahirlah berbagai perangkat perundang-undangan pidana di luar Kitab Undang-undang Hukum Pidana (KUHP). Undang-undang dimaksud mengatur antara lain tindak pidana di bidang pengelolaan lingkungan hidup, pasar modal, bea dan cukai, pemberantasan tindak pidana korupsi, perbankan, pencucian uang (money laundering), perdagangan manusia (human trafficking) dan nakotika.

Lahirnya bentuk-bentuk kejahatan baru yang sering disebut sebagai kejahatan kerah putih (white collar crime), tidak serta merta menghapuskan bentuk kejahatan konvensional seperti penipuan, penggelapan, perkosaan, penganiayaan, perampokan, pembunuhan, pencurian dan pencurian dengan kekerasan.

Diantara bentuk kejahatan konvensional tersebut di atas, terdapat sejumlah tindak pidana yang berpotensi menyebabkan gangguan keamanan, ketertiban dan ketentraman atau menimbulkan keresahan di tengah masyarakat. Salah satu dari tindak pidana tersebut adalah kejahatan jalanan yang dilakukan oleh sejumlah orang yang tergabung dalam komunitas kendaraan bermotor roda dua, yang seringkali disebut sebagai geng motor.

Fenomena yang terjadi saat ini adalah bahwa tingkat kejahatan jalanan di hampir seluruh kota besar di Indonesia, mengalami perubahan pada strata pelaku. Kejahatan jalanan yang dulunya didominasi oleh kelompok-kelompok penjahat kambuhan, kini justru didominasi oleh kelompok baru dari kalangan pelajar dan bekas pelajar yang menganggur. Mereka bermutasi menjadi gerombolan geng motor.

Mereka sejatinya bukan kelompok kriminal murni. Namun aksi-aksinya di jalanan, kerap lebih mengerikan dari kelompok penjahat profesional. Dengan sederet bentuk kejahatan konvensional yang mereka lakoni, justru menjadi kelompok paling ditakuti warga. Berawal dari aksi-aksi balapan liar, kemudian perilaku mereka berkembang pada tindakan yang mengarah pada kejahatan murni. Diantaranya, penodongan, perampasan, pemerkosaan hingga penganiayaan yang berujung pada pembunuhan.

Dari waktu ke waktu, keberingasan geng motor memang mengarah ke tindak kriminal murni. Sejumlah sesepuh geng motor tidak menampik bahwa geng-geng motor sekarang bisa saja dijadikan sarana peredaran narkoba. Dulu saja banyak bandar yang menawarkan barangnya. Waktu itu zamannya putaw sedang tren. Harus diakui, ada beberapa anggota geng yang memakainya, bahkan menjualnya ke anggota geng lainnya. Bukan tidak mungkin, geng-geng motor itu suatu saat nanti berkembang menjadi kelompok kejahatan yang terorganisasi. Oleh karena itu, polisi harus berani bertindak tegas terhadap 
geng motor sebelum mereka menjadi kelompok kejahatan terorganisasi. Mereka memang bisa saja "membakar" jalanan Kota Bandung dengan segala aksi kriminal, layaknya geng motor Hell's Angels yang "membakar" jalanan di Benua Amerika. ${ }^{1}$

Berdasarkan paparan di atas, menjadi jelas betapa serius bahkan mengerikannya dampak buruk dari kegiatan geng motor terhadap keamanan, ketertiban dan ketentraman di tengah masyarakat. Pada sisi lain, rentetan kejadian keganasan dan kebrutalan kelompok geng motor, semakin menggugah kesadaran bersama betapa perlunya dilakukan penegakan hukum yang keras dan bersifat komprehensif terhadap pelaku, sedemikian sehingga kegiatan kelompok jalanan tersebut bisa diberantas, dan korban-korban tidak lagi berjatuhan.

Dalam perspektif perundang-undangan Indonesia, terhadap pelaku kejahatan jalanan yang dilakukan secara bersama-sama, dapat dikenakan ketentuan pidana sebagaimana termaktub di dalam Kitab Undang-Undang Hukum Pidana (KUHP), dan ketentuan pidana khusus seperti pidana yang berkaitan dengan lalu lintas sebagaimana diatur di dalam Undang-Undang Nomor 22 Tahun 2009 tentang Lalu Lintas dan Angkutan Jalan (selanjutnya disebut Undang-Undang Lalu Lintas dan Angkutan Jalan), atau ketentuan pidana yang berhubungan dengan narkotika sebagaimana diatur di dalam Undang-Undang Nomor 35 Tahun 2009 tentang narkotika (selanjutnya disebut UndangUndang Narkotika).

Dalam kaitannya dengan tindak pidana umum, sebutlah penganiayaan misalnya, maka kelompok geng motor yang melakukan penganiayaan, dapat dikenakan ketentuan pidana Pasal 351 KUHP, yang selengkapnya menyatakan bahwa:

Pasal 351

(1) Penganiayaan diancam dengan pidana penjara paling lama dua tahun delapan bulan atau pidana denda paling banyak empat ribu lima ratus rupiah,

(2) Jika perbuatan mengakibatkan luka-luka berat, yang bersalah diancam dengan pidana penjara paling lama lima tahun.

(3) Jika mengakibatkan mati, diancam dengan pidana penjara paling lama tujuh tahun.

(4) Dengan penganiayaan disamakan sengaja merusak kesehatan.

${ }^{1}$ http://moonrakerindonesia.blogspot.com/2010/07/geng-motor-membakar-jalanan-kota.html. 
(5) Percobaan untuk melakukan kejahatan ini tidak dipidana.

Mencermati ketentuan Pasal 351 KUHP di atas, diperoleh kesimpulan sementara bahwa pengenaan Pasal 351 KUHP kepada anggota geng motor yang melakukan tindak pidana penganiayaan dirasakan tidak tepat, karena Pasal tersebut cenderung melihat kejahatan penganiayaan sebagai perbuatan pribadi, atau perbuatan yang dilakukan oleh seorang pelaku.

Hal itu sama sekali berbeda halnya dengan kejahatan yang dilakukan oleh kelompok geng motor. Kejahatan penganiayaan kelompok jalanan ini, dilakukan secara bersama-sama, bahkan melibatkan puluhan sampai ratusan pelaku, dengan cara-cara yang tergolong brutal bahkan biadab.

Dengan karakteristik tindak pidana yang demikian, maka penerapan Pasal 351 KUHP terhadap gerombolan geng motor yang melakukan penganiayaan, menjadi tidak tepat. Meskipun dirasakan tidak tepat, disadari penerapan pasal itu adalah satu-satunya pilihan yang ada di dalam KUHP. Dengan kata lain, KUHP yang berlaku saat ini belum mengatur tentang pidana penganiayaan yang dilakukan secara bersama-sama, oleh kelompok terogranisir, dan dengan cara-cara yang di luar batas kemanusiaan.

Dengan demikian, disimpulkan bahwa dalam kaitan dengan pidana umum, terdapat kekosongan norma (vacuum of norm) di dalam KUHP yang mengatur tentang ketentuan pidana, yang dilakukan secara bersama-sama, oleh kelompok terogranisir, dan dengan cara-cara yang brutal bahkan biadab. Ketiadaan norma tersebut cenderung menyebabkan rendahnya sanksi pidana yang dapat dijatuhkan kepada pelaku pidana geng motor, sedemikian sehingga tidak menimbulkan efek jera (deterrent aspect). Tidak adanya efek jera tersebut, menyebabkan perkembang-biakan geng motor sulit dihentikan, yang pada gilirannya melemahkan penegakan hukum di tengah masyarakat.

\section{B. Perumusan Masalah}

Adapun pertanyaan-pertanyaan penelitian yang memfokuskan permasalahan di atas adalah:

1. Bagaimana pengaturan mengenai perbuatan pidana yang dilakukan oleh geng motor menurut hukum pidana Indonesia?;

2. Bagaimana konsepsi pembaharuan hukum pidana tentang perbuatan pidana yang dilakukan oleh geng motor, sedemikian sehingga mampu mencapai hakekat 
penegakan hukum, yakni menciptakan menciptakan ketertiban, guna mencapai keadilan, dan hukum sebagai alat pembaharuan masyarakat?.

\section{Metode Penelitian}

1. Tipe Penelitian

Mengacu pada perumusan masalah dan tujuan penelitian tersebut di atas, maka penelitian ini dilakukan dengan menggunakan penelitian yuridis normatif. Penelitian hukum normatif mencakup penelitian terhadap asas-asas hukum, sistematika hukum, sinkronisasi hukum, dan sejarah hukum. Penelitian normatif diambil sebagai pendekatan utama dalam penelitian ini karena yang menjadi perhatian utama adalah ketentuan KUHP, yang mengatur mengenai perbuatan pidana yang dilakukan oleh gerombolan geng motor.

\section{Pendekatan Penelitian}

Pendekatan yang digunakan dalam penelitian ini, sesuai dengan rumusan masalah sebagai objek penelitian yang akan dibahas dan dijawab. Maka pendekatan yang digunakan pendekatan konseptual, pendekatan peraturan perundang-undangan dan pendekatan sejarah. Pendekatan Konsep dilakukan dengan meneliti asas-asas hukum pidana, teori-teori kebijakan kriminal, kebijakan hukum pidana dan teori pemidanaan. Pendekatan perundang-undangan dilakukan dengan meneliti konsep perundang-undangan yang relevan dengan penelitian ini, baik berbentuk hukum positif maupun yang masih berbentuk rancangan. Sementara pendekatan sejarah dikakukan dengan meneliti latar belakang pengaturan mengenai perbuatan pidana yang dilakukan oleh gerombolan geng motor.

Setelah bahan-bahan hukum tersebut terkumpul, maka dilakukan analisis terhadap pengertian-pengertian hukum dan norma-norma hukum, dengan cara melihat isi dari berbagai macam peraturan perundang-undangan yang berhubungan dengan masalah proses peradilan pidana. Pengkajian terhadap isi bahan hukum dengan melakukan interpretasi, menilai dan melakukan evaluasi terhadap semua kebijakan hukum pidana yang berhubungan dengan masalah pemidanaan, hukum acara pidana, sistem peradilan pidana baik berupa hukum positif maupun yang masih berbentuk konsep.

\section{Kajian yuridis terhadap perbuatan pidana yang dilakukan oleh geng motor menurut hukum pidana Indonesia}


1. Analisis Pengaturan Mengenai Perbuatan Pidana yang Dilakukan oleh Geng Motor Menurut Hukum Pidana Indonesia

Sebelum sampai pada pembahasan mengenai pengaturan tentang perbuatan pidana yang dilakukan oleh geng motor menurut hukum pidana Indonesia, perlu ditinjau terlebih dahulu pengertian dari geng motor, karakteristik kejahatan yang dilakukannya, dan dampak dari perbuatan pidana yang dilakukan oleh geng motor.

Menurut Kamus Besar Bahasa Indonesia, geng berarti sebuah kelompok atau gerombolan remaja yang dilatar-belakangi oleh persamaan latar sosial, sekolah, daerah dan sebagainya. Pelakunya dikenal dengan sebutan gangster. Gangster atau bandit berarti suatu anggota dalam sebuah kelompok kriminal (gerombolan) yang terorganisir dan memiliki kebiasaan urakan dan anti peraturan. Geng motor sendiri dilandasi oleh aktivitas kesenangan di atas motor. Namun yang perlu untuk digarisbawahi, pengertian geng motor sangatlah berbeda dengan pengertian $c l u b$ motor. Pada $c l u b$ motor, aktivitas berkelompok didasari oleh kesamaan hobi otomotif atau aktivitas sosial yang umumnya terdaftar pada organisasi otomotif resmi, seperti IMI (Ikatan Motor Indonesia). ${ }^{2}$

Sebuah geng motor biasanya memiliki beberapa sektor yang penamaannya berdasarkan nama wilayah atau daerah. Bahkan aktivitas penyisirannyapun diatur dan dikomandoi oleh seorang koordinator sektor, yang dalam menjalankan aksinya mereka memilki strategi perang untuk menyerang dan bertahan, bahkan memiliki senjata andalan seperti tongkat, pedang ataupun senjata api. Keberadaan geng motor dianggap sebagai kelompok kriminal yang perlu mendapat penangganan serius dari aparat penegak hukum mengingat aksi mereka sangat meresahkan masyarakat. ${ }^{3}$

Pandangan senada dikemukakan oleh Muchlis bahwa geng motor adalah istilah yang sama sekali berbeda dengan klub motor. Geng motor memiliki karakteristik sebagai berikut:

1. Kebanyakan anggota geng motor tidak memakai perangkat keselamatan seperti helm, sepatu dan jaket;

2. Membawa senjata yang dibuat sendiri atau buatan pabriknya seperti rantai besi yang telah ditajamkan, samurai, badik, bom Molotov, hingga senjata api;

\footnotetext{
${ }^{2}$ Trias Palupi Kurnianingrum, “Geng Motor dari Sisi Penegakan Hukum”, Jurnal Info Singkat Hukum, Vol. IV, No. 08/II/P3DI/April/2012.

${ }^{3}$ Trias Palupi Kurnianingrum, "Geng Motor dari Sisi Penegakan Hukum”, Jurnal Info Singkat Hukum, Vol. IV, No. 08/II/P3DI/April/2012.
} 
3. Biasanya hanya muncul malam hari dan tidak menggunakan lampu penerang serta bunyi kendaraan yang memekakkan telinga;

4. Jauh dari kegiatan sosial, tidak pernah membuat acara-acara sosial.

5. Anggotanya lebih banyak anak-anak di bawah umur, pelajar atau bekas pelajar. Lebih banyak lelaki daripada perempuan, dan perempuan tidak jarang dijadikan pemuas seks anggota laki-laki;

6. Motor yang digunakan tidak memiliki surat-surat yang lengkap atau bodong, tidak ada spion, sein, hingga lampu utama;

7. Yang penting buat mereka adalah motor bisa kencang dan mampu melibas orang yang lewat. Visi dan misi mereka jelas, hanya membuat kekacauan dan ingin menjadi geng terseram diantara geng motor lainnya hingga sering terjadi tawuran di atas motor;

8. Suka berkumpul di tempat-tempat yang gelap. ${ }^{4}$

Sedangkan klub motor, memiliki ciri-ciri atau karakteristik sebagai berikut:

1. Perlengkapan keselematan dalam berkendara benar-benar lengkap;

2. Motor dan pengendaranya sama-sama lengkap bahkan biasanya ditambah box dibelakang motor, untuk menaruh helm dan peralatan motor;

3. Berkumpul di tempat yang ramai agar bisa dilihat masyarakat, sekaligus ajang silahturahmi kepada klub motor lain yang kebetulan melintas.

4. Mempunyai visi dan misi yang jelas dan jauh dari ruang lingkup yang anarkis.

5. Melakukan kegiatan touring ke daerah-daerah sembari membagikan sumbangan.

6. AD/ART jelas dan tercatat di Kepolisian atau wadah dari perkumpulan klub motor.

7. Saling tolong menolong terhadap anggota klub motor lain ketika di jalan mendapatkan trouble.

8. Setiap klub motor memiliki tujuan dalam berkendara dan peraturan-peraturan yang tidak membebankan anggotanya. ${ }^{5}$

Berdasarkan karakteristik geng motor tersebut di atas, ditarik pengertian bahwa geng motor adalah kumpulan terorganisir yang umumnya beranggotakan anak-anak muda, pejalar dan bekas pelajar yang menganggur. Anggota geng motor pada umumnya

\footnotetext{
${ }^{4}$ Jurnal Ilmu Komunikasi, Vol. 1, No.2, Oktober 2011, ISSN: 2088-981X.

${ }^{5}$ Jurnal Ilmu Komunikasi, Vol. 1, No.2, Oktober 2011, ISSN: 2088-981X.
} 
mengenadarai motor secara bergeromboalan, tanpa mengindahkan peraturan lalu lintas dan keselamatan pemakai jalan lainnya, dan biasanya membekali diri dengan senjata, yang terdiri dari aneka senjata tajam, bom molotov, dan senjata api. Adapun tujuan dari kegiatan geng motor adalah membuat keresahan di tengah masyarakat, tawuran antar sesama geng motor, hingga untuk tujuan melakukan perbuatan pidana.

Dengan kehadiran geng motor, kejahatan jalanan yang dulunya didominasi oleh kelompok-kelompok penjahat kambuhan, kini justru didominasi oleh kelompok baru dari geng motor, yang sebagian besar merupakan kalangan anak muda, pelajar dan bekas pelajar.

Mereka sejatinya bukan kelompok kriminal murni. Namun aksi-aksinya di jalanan, kerap lebih mengerikan dari kelompok penjahat profesional. Dengan sederet bentuk kejahatan konvensional yang mereka lakoni, geng motor justru menjadi kelompok paling ditakuti warga.

Berawal dari aksi-aksi balapan liar, kemudian perilaku mereka berkembang pada tindakan yang mengarah pada kejahatan. Kawanan geng motor yang selalu bergerombolan dan membawa aneka sejata tajam bahkan senjata api ini, tidak segan-segan menganiaya korban, memperkosa bahkan membunuh.

Peristiwa demi peristiwa keganasan geng motor bagai tidak pernah berhenti diberitakan di media. Sepanjang yang terpantau di media, kelompok geng motor yang tergenal ganas dan sadis, antara lain terdapat di Bandung, Jakarta, Medan, Pekanbaru, Palembang,dan Makassar.

Dalam melakukan kejahatan, para anggota geng yang mengendarai motor yang secara bergerombolan, serta merta telah melakukan tindak pidana lalu lintas yang sangat mengganggu ketentraman masyarakat. Mulai dari tindak pidana ringan seperti kendaraan bermotor yang tidak dilengkapi dengan surat menyurat dan kelengkapan peralatan, sampai tindak pidana berat seperti karena kelalaiannya dalam mengemudikan kendaraan atau ugal-ugalan di jalan, yang menyebabkan jatuhnya korban luka bahkan meninggal.

Di samping itu, geng-geng motor sekarang juga dijadikan sarana peredaran narkotika. Di dalamnya, banyak bandar yang menawarkan barang. Waktu itu zamannya putaw sedang tren, mereka memakai putaw secara bersama-sama. Harus diakui, ada beberapa anggota geng yang memakainya, bahkan menjualnya ke anggota geng lainnya. Bukan tidak mungkin, geng-geng motor itu suatu saat nanti berkembang menjadi kelompok kejahatan narkotika yang terorganisasi. Mereka memang bisa saja "membakar" jalanan 
Kota dengan segala aksi kriminal, lalu lintas, narkoba, perkosaan, perampokan, dan pembunuhan, layaknya geng motor Hell's Angels yang "membakar" jalanan di Benua Amerika. ${ }^{6}$

Geng motor tengah menjadi sorotan akhir-akhir ini. Pengeroyokan yang melibatkan kelompok pengendara motor dan oknum tentara terjadi hampir tiga pekan terakhir, polisi dan militer sampai harus menggelar operasi khusus bagi pengendara motor. Data Indonesia Police Watch mengungkapkan setiap tahun lebih dari 60 orang tewas karena ulah geng motor. Sebanyak 65 orang tewas pada tahun 2013 akibat geng motor. ${ }^{7}$

Berdasarkan deskripsi mengenai tindakan meresahkan dari sebagian genk motor tersebut di atas, dapat ditarik kesimpulan bahwa geng motor adalah kelompok atau gerombolan terorganisir yang ditinjau dari perilaku kelompoknya, memiliki maksud (mens rea) melakukan perbuatan pidana.

Berangkat dari paparan di atas, menjadi jelas betapa serius bahkan mengerikannya dampak buruk dari kegiatan geng motor terhadap keamanan, ketertiban dan ketentraman masyarakat. Pada sisi lain, rentetan kejadian keganasan dan kebrutalan kelompok geng motor, semakin menggugah kesadaran bersama betapa perlunya dilakukan penegakan hukum yang keras namun bersifat komprehensif terhadap pelaku, sedemikian sehingga kegiatan kelompok jalanan tersebut bisa diberantas, dan korban-korban tidak lagi berjatuhan.

Dalam perspektif perundang-undangan Indonesia yang berlaku saat ini, terhadap pelaku kejahatan jalanan yang dilakukan secara bersama-sama, dapat dikenakan ketentuan pidana sebagaimana termaktub di dalam Kitab Undang-Undang Hukum Pidana (KUHP), dan ketentuan pidana khusus seperti pidana yang berkaitan dengan lalu lintas sebagaimana diatur di dalam Undang-Undang Lalu Lintas dan Angkutan Jalan, atau ketentuan pidana yang berhubungan dengan narkotika sebagaimana diatur di dalam Undang-Undang Narkotika.

Perbuatan pidana yang paling sering dilakukan oleh geng motor antara lain adalah pencurian yang oleh karenanya dikenakan Pasal 363 KUHP, pencurian dengan kekerasan (Pasal 365 KUHP), pemerkosaan (Pasal 285 KUHP), penganiayaan (Pasal 351 UKHP), atau tindak pidana pembunuhan (Pasal 338 KUHP), dan tindak pidana narkotika (Pasal 112 - 117 Undang-Undang Narkotika).

${ }^{6} \mathrm{http}: / /$ moonrakerindonesia.blogspot.com/2010/07/geng-motor-membakar-jalanan-kota.html.

7 http://www.tempo.co/read/news/2012/04/17/064397631/Ini-Geng-Motor-Paling-Ditakuti-diJakarta-Bandung. 
Di samping itu, karena mengendarai motor tanpa mengindahkan keselamatan dan nyawa orang lain, geng motor dapat dikenakan perbuatan pidana mengganggu ketertiban umum, dan atau pidana berupa pelanggaran lalu lintas.

Dalam kaitannya dengan penegakan hukum yang lebih keras terhadap anggota geng motor yang melakukan tindak pidana, pertanyaan yang muncul adalah apakah KUHP dan perundang-undangan di luar KUHP, telah memuat ketentuan pidana khusus tentang perbuatan pidana dan sanksi pidana yang lebih berat terhadap pelaku tindak pidana, yang dalam melakukan tindak pidana itu tidak sendirian, melainkan berkelompok dalam gerombolan, dan cara melakukan tindak pidana itu, dilakukan dengan cara-cara yang sadis di luar batas-batas kemanusiaan.

Untuk menjawab pertanyaan di atas, diambil salah satu ketentuan pidana di dalam KUHP, yakni Pasal 351 tentang penganiayaan. Ketentuan Pasal 351 diambil sebagai contoh kasus, karena perbuatan pidana penganiayaan adalah perbuatan pidana yang paling banyak dilakukan oleh geng motor.

Dari pengkajian tentang ketentuan Pasal 351 KUHP tersebut, diharapkan dapat ditarik kesimpulan apakah pengenaan pasal-pasal KUHP terhadap perbuatan pidana yang dilakukan oleh geng motor, sudah merupakan tindakan yang tepat dalam memberikan pemberatan pidana, ataukah diperlukan ketentuan khusus yang mengatur tentang perbuatan pidana yang dilakukan oleh geng motor, agar pemidanaannya menjadi lebih berat.

Ketentuan Pasal 351 KUHP, selengkapnya menggariskan sebagai berikut:

Pasal 351

(1) Penganiayaan diancam dengan pidana penjara paling lama dua tahun delapan bulan atau pidana denda paling banyak empat ribu lima ratus rupiah,

(2) Jika perbuatan mengakibatkan luka-luka berat, yang bersalah diancam dengan pidana penjara paling lama lima tahun.

(3) Jika mengakibatkan mati, diancam dengan pidana penjara paling lama tujuh tahun.

(4) Dengan penganiayaan disamakan sengaja merusak kesehatan.

(5) Percobaan untuk melakukan kejahatan ini tidak dipidana.

Menurut ayat (4) dari Pasal 351 KUHP di atas, yang disamakan dengan penganiayaan yaitu: "sengaja merusak kesehatan orang”. 1) "Menyebabkan perasaan tidak 
enak" misalnya: mendorong orang terjun ke kali, sehingga basah kuyup, suruh orang berdiri berjam-jam di teri matahari dan sebagainya. 2) "Rasa sakit" artinya "pijn" bukan "ziek", misalnya mencubit, mendupak, memukul, menempeleng dan sebagainya. 3) "Luka" misalnya: mengiris, menusuk, memotong dengan pisau dan sebagainya hingga terluka. 4) "Mersak kesehatan orang" misalnya orang sedang tidur dan berkeringat, dibuka jendela kamarnya, sehingga orang itu masuk angin, member minum orang dengan racun atau bahan-bahan yang merugikan, sehingga orang itu menjadi sakit (terganggu kesehatannya). ${ }^{8}$ Semuanya itu harus dilakukan dengan sengaja dan tanpa maksud yang patut atau melewati batas yang diizinkan. Umpamanya seorang dokter gigi mencabut gigi dari pasiennya. Sebenarnya ia sengaja menimbulkan rasa sakit, akan tetapi perbuatannya bukan penganiayaan, bahkan perbuatan sosial, oleh karena itu ada maksud baik (mengobati). Seorang bapak memukul pada anaknya dengan tangan, karena anak itu nakal. Inipun sebenarnya suatu penganiayaan, karena sengaja menimbulkan rasa sakit, tetapi oleh karena ada maksud yang patut (mengajar) peristiwa itu tidak dianggap sebagai penganiayaan yang dapat dihukum. ${ }^{9}$

Walaupun demikian kedua peristiwa tersebut di atas bila dilakukan dengan "melewati batas yang diizinkan", misalnya dokter tadi mencabut gigi sengaja tidak memakai suntikan pati rasa, dan dengan secara sambil senda gurau, atau seorang bapak tadi mengajar anaknya memukul dengan sepotong besi dan dikenakan pada kepalanya, maka perbuatan-perbuatan itupun dipandang sebagai penganiayaan yang dapat dihukum. ${ }^{10}$

Merujuk pada ketentuan Pasal 351 KUHP dan penjelasan ahli hukum pidana di atas, terlihat dengan jelas bahwa dalam ketentuan pidana yang mengatur mengenai perbuatan dan sanksi pidana penganiayaan, membedakan ancaman pidana yang dapat dikenakan hanya berdasarkan akibat yang timbul dari suatu perbuatan pidana, tanpa mempertimbangkan unsur jumlah jumlah pelaku yang melakukan tindak pidana bersangkutan.

Artinya, semakin berat penderitaan yang dialami oleh korban penganiayaan, akan semakin tinggi pula ancaman pidana yang dapat dijatuhkan terhadap pelaku, tanpa harus melihat apakah yang melakukan penganiayaan itu, seorang diri atau melakukannya beramai-ramai dalam kelompok yang terorganisir.

\footnotetext{
${ }^{8}$ Ibid.

${ }^{9}$ Ibid.

${ }^{10}$ Ibid., hal. 144-145.
} 
Dengan kata lain, unsur jumlah pelaku bukanlah merupakan dasar pertimbangan dalam menentukan lamanya ancaman pidana yang dapat dijatuhkan terhadap pelaku pidana penganiayaan. Ancaman pidana adalah sama, apakah perbuatan penganiayaan itu dilakukan oleh satu orang, atau dilakukan secara bersama-sama, dalam kelompok yang terorganisir.

Karena hanya mempertimbangkan akibat dari tindak pidana, tanpa mempertimbangkan jumlah pelaku tindak pidananya, maka penerapan Pasal 351 KUHP terhadap pelaku geng motor, yang melakukan tindak pidana penganiayaan dalam kelompok yang terorganisir, dirasakan tidak akan dapat mencapai hakikat dari penegakan hukum, yakni terpenuhinya asas keadilan dan kepastian hukum.

Ketidak-adilan akan segera dirasakan, terutama oleh korban atau keluarganya, manakala perbuatan pidana penganiayaan yang dilakukan oleh segerombolan orang, puluhan bahkan bisa mencapai ratusan orang dengan cara-cara yang sadis di luar batas kemanusiaan, disamakan ancaman pidananya dengan penganiayaan yang dilakukan oleh satu orang pelaku pidana penganiayaan saja.

Konon lagi, kalau mengingat bahwa perlakuan penganiayaan yang beringas tersebut, harus dialami oleh korban yang sama sekali tidak ada sangkut pautnya, atau tidak tahu menahu dengan pelaku pidana. Dapatlah dibayangkan berapa mirisnya perasaan dan penderitaan fisik maupun batin dari korban dan/atau keluarganya, akibat penganiayaan membabi buta yang mesti dialami oleh korban yang tidak berdosa itu.

Ditilik dari pencapaian asas kepastian hukum, penerapan Pasal 351 KUHP terhadap pelaku yang berasal dari geng motor, juga dirasakan tidak tepat. Dengan penerapan Pasal 351 KUHP terhadap geng motor, maka ancaman pidana yang dapat dikenakan terhadap pelaku akan relatif ringan.

Rendahnya sanksi pidana yang dapat dijatuhkan kepada pelaku pidana geng motor, jelas tidak akan mampu menimbulkan efek jera (deterrent aspect), baik terhadap pelaku maupun kelompok geng motor lain agar tidak melakukan perbuatan yang sama. Dengan keadaan yang demikian, geng motor akan terus berkembang biak, sulit dihentikan, dan semakin meresahkan masyarakat, yang pada gilirannya akan melemahkan penegakan hukum di tengah masyarakat.

Setelah mencermati ketentuan pasal-pasal lain baik di dalam KUHP, maupun dalam perundang-undangan pidana di luar KUHP, ditemukan prinsip perumusan ketentuan pidana 
yang sama dengan ketentuan Pasal 351 KUHP, bahwa sanksi pidana ditentukan oleh besarnya akibat dari perbuatan pidana yang dilakukan.

Dengan demikian, dapat disimpulkan bahwa dalam perspektif hukum pidana Indonesia yang berlaku saat ini, terhadap perbuatan pidana yang dilakukan oleh geng motor, seperti pencurian, pencurian dengan kekerasan, pemerkosaan, dan pembunuhan, dikenakan pasal-pasal yang diatur di dalam KUHP. Di samping itu, terhadap penggunaan dan peredaran gelap narkotika, dikenakan pasal-pasal dalam Undang-Undang Narkotika, sementara pidana mengganggu ketertiban umum, dan/atau pidana berupa pelanggaran lalu lintas, dikenakan ketentuan pidana sebagaimana diatur di dalam Undang-Undang Lalu Lintas dan Angkutan Jalan. Pengenaan pasal-pasal dimaksud terhadap perbuatan pidana yang dilakukan oleh geng motor, tidak akan mampu memenuhi asas keadilan dan kepastian hukum, yang menjadi tujuan mendasar dari penegakan hukum. Hal itu disebabkan karena perbuatan pidana yang dilakukan oleh geng motor, memiliki karakteristik khusus antara lain dilakukan secara berkelompok, terorganisir, cara-cara yang sadis di luar batas-batas kemanusiaan, dan jumlah korban yang banyak, sedemikian sehingga harus dipidana dengan pidana yang lebih berat. Pemidanaan yang relatif ringan sebagaimana diatur di dalam KUHP dan perundang-undangan pidana di luar KUHP sebagaimana yang berlaku saat ini, tidak akan menimbulkan efek penjeraan (deterrence aspect). baik terhadap pelaku maupun kelompok geng motor lain agar tidak melakukan perbuatan yang sama. Dengan keadaan yang demikian, geng motor akan terus berkembang biak, sulit dihentikan, dan semakin meresahkan masyarakat, yang pada gilirannya akan melemahkan penegakan hukum di tengah masyarakat.

2. Konsepsi Norma Perbuatan Pidana yang Dilakukan Oleh Geng Motor yang Sebaiknya Diterapkan di Masa Depan

Telah dikemukakan dalam kesimpulan pada bagian sebelumnya, bahwa terhadap perbuatan pidana yang dilakukan oleh geng motor, masih dikenakan ketentuan pasal-pasal dengan ancaman pidana, yang dinilai tidak sebanding dengan tingkat kekejaman/kesadisan pelaku, akibat perbuatan pidana atau derita yang harus ditanggung oleh korban/keluarga.

Oleh karena itu, maka rekonstruksi pemikiran tentang norma perbuatan pidana geng motor yang sebaiknya diterapkan di masa depan, berangkat dari cara bagaimana merumuskan perbuatan pidana yang dilakukan oleh geng motor, dengan ancaman pidana yang lebih tinggi dari ancaman pidana yang saat ini berlaku di dalam KUHP. 
Dengan ancaman pidana yang lebih tinggi dari sanksi pidana dalam pasal-pasal berkaitan di dalam KUHP saat ini, diharapkan penegakan hukum terhadap geng motor dapat dilakukan secara lebih tegas dan keras, sedemikian sehingga pertumbuhan geng motor yang makin merebak dengan tindakan-tindakannya yang sangat meresahkan masyarakat, dapat dicegah dan diberantas.

Terkait dengan perumusan perbuatan pidana yang dilakukan oleh geng motor, dapat dilakukan dengan mempertimbangkan bahwa perbuatan pidana yang dilakukan oleh geng motor adalah jenis perbuatan pidana yang sama dengan perbuatan pidana di dalam KUHP. Maka dari itu, unsur-unsur tindak pidana berkaitan yang saat ini sudah ada di dalam KUHP seperti unsur-unsur tindak pidana pencurian, pencurian dengan kekerasan, pemerkosaan, dan pembunuhan, dapat diadopsi sedemikian rupa menjadi unsur-unsur tindak pidana yang dilakukan oleh geng motor.

Sementara dalam perumusan sanksi pidana, direkomendasikan untuk melakukan pemberatan pidana terhadap geng motor yang melakukan tindak pidana, dengan pemberatan berupa penambahan $1 / 3$ (satu per tiga) dari pidana yang ditetapkan untuk perbuatan pidana biasa.

Adapun dalam teknisnya, pemuatan ketentuan tentang perbuatan pidana geng motor dapat menjadi bagian dari ketentuan pasal-pasal pidana yang sudah ada dalam KUHP saat ini. Denga kata lain, ketentuan pidana yang mengatur tentang perbuatan pidana geng motor dapat menjadi salah satu ayat di dalam ketentuan pidana berkaitan yang sdah ada dalam KUHP saat ini.

Sebagai contoh, dapat dikemukakan revisi Pasal 351 KUHP yang telah mengadopsi perbuatan penganiayaan yang dilakukan geng motor sebagai berikut:

Pasal 351

(1) Penganiayaan diancam dengan pidana penjara paling lama dua tahun delapan bulan atau pidana denda paling banyak empat ribu lima ratus rupiah,

(2) Jika perbuatan mengakibatkan luka-luka berat, yang bersalah diancam dengan pidana penjara paling lama lima tahun.

(3) Jika mengakibatkan mati, diancam dengan pidana penjara paling lama tujuh tahun.

(4) Dengan penganiayaan disamakan sengaja merusak kesehatan.

(5) Percobaan untuk melakukan kejahatan ini tidak dipidana. 
(6) Apabila penganiayaan dilakukan oleh geng motor, maka pidana terhadap masing-masing pelaku ditambah 1/3 (satu per tiga).

Di samping penegakan hukum yang bersifat lebih keras, dengan penerapan ancaman pidana yang lebih berat sebagaimana dikemukakan di atas, penegakan hukum terhadap pelaku pidana yang merupakan anggota geng motor, juga harus dilakukan secara komprehensif.

Penegakan hukum yang bersifat komprehensif sangat diperlukan, karena mengingat setidaknya 2 (dua) hal. Pertama, keberadaan geng motor sangat berkaitan erat dengan tingkat kesejahteraan masyarakat. Kedua, karena sebagian besar dari pelaku pidana geng motor adalah anak di bawah umur, yang secara hukum keberadaannya justru harus dilindungi.

Demi mengingat kedua hal tersebut di atas, maka pengaturan tentang perbuatan pidana yang dilakukan oleh geng motor, haruslah didahului oleh upaya-upaya pencegahan yang bersifat non penal. Deteksi dini terhadap keberadaan geng motor, haruslah dikedepankan daripada upaya pemberantasan dengan penangkapan dan pemidanaan pelaku. Dengan demikian, pemidanaan hendaknya menjadi pilihan terakhir (ultimum remedium).

Persoalan geng motor, jelas tidak akan dapat diberantas sampai ke akar-akarnya, manakala hanya diserahkan kepada penegakan hukum pidana semata. Orang tua, guru dan sekolah, tokoh agama, tokoh masyarakat, dan pemerintah haruslah saling bahu membahu menuntaskan kenakalan remaja sebagai embrio terjadinya kejahatan oleh geng motor.

Di tengah upaya non penal yang tidak dilakukan secara lintas sektor, dan tidak tumbuh kesadaran bersama akan bahaya serius yang akan menggerogoti generasi muda kita akibat geng motor, maka upaya penal berupa penegakan hukum pidana yang dilakukan dengan mengenakan sanksi pidana yang lebih berat kepada pelaku pidana geng motor, diyakini tidak akan mencapai hasil sebagaimana yang diinginkan.

Berdasarkan uraian di atas, diperoleh kesimpulan bahwa untuk mengatasi keresahan masyarakat akibat maraknya kejahatan yang dilakukan oleh geng motor, harus dilakukan upaya hukum dengan menerapkan ancaman pidana yang lebih berat terhadap pelaku tindak pidana yang berasal dari geng motor. Penerapan pidana yang lebih berat tersebut dilakukan melalui revisi atau perubahan/penambahan ketentuan pasal-pasal pidana terkait seperti pasal pencurian, pencurian dengan kekerasan, pemerkosaan atau pasal pembunuhan di dalam KUHP yang berlaku saat ini, dengan ayat yang menyatakan bahawa "apabila 
tindak pidana dalam pasal ini dilakukan oleh geng motor, maka pidana terhadap masingmasing pelaku ditambah 1/3 (satu per tiga)". Namun demikian, upaya hukum tersebut haruslah didahului dengan upaya pencegahan yang bersifat non hukum, antara lain berupa kerjasama lintas sektor untuk mendeteksi secara dini keberadaan geng motor, dan mengatasi masalah-masalah sosial yang menyebabkan kenakalan remaja sebagai embrio dari kejahatan serius yang dilakukan oleh geng motor.

\section{E. Kesimpulan}

Berdasarkan uraian pada bab terdahulu, maka dapat diambil beberapa kesimpulan sebagai berikut:

1. Dalam perspektif hukum pidana Indonesia, terhadap perbuatan pidana yang dilakukan oleh geng motor, dikenakan pasal-pasal yang diatur di dalam KUHP. Di samping itu, terhadap perbuatan pidana yang bersifat khusus, dikenakan pasalUndang-Undang Narkotika, atau Undang-Undang Lalu Lintas dan Angkutan Jalan. Pengenaan pasal-pasal dimaksud, diyakini tidak akan mampu memenuhi asas keadilan dan kepastian hukum, karena karkateristik perbuatan pidana geng motor yang bersifat khusus. Perbuatan pidana yang dilakukan oleh geng motor, dilakukan secara berkelompok, terorganisir, dengan cara-cara yang sadis di luar batas-batas kemanusiaan, dan jumlah korban yang banyak, sedemikian sehingga harus dipidana dengan pidana yang lebih berat. Pemidanaan yang relatif ringan sebagaimana diatur di dalam KUHP dan perundang-undangan di luar KUHP, tidak akan menimbulkan efek penjeraan (deterrence aspect). Dengan keadaan yang demikian, geng motor akan terus berkembang biak, sulit dihentikan, dan semakin meresahkan masyarakat, yang pada gilirannya akan melemahkan penegakan hukum di tengah masyarakat.

2. konsepsi pembaharuan hukum pidana tentang perbuatan pidana yang dilakukan oleh geng motor, yang sebaiknya diterapkan agar mampu mencapai hakekat penegakan hukum, yakni menciptakan menciptakan ketertiban, guna mencapai keadilan, dan hukum sebagai alat pembaharuan masyarakat, adalah penerapan menerapkan ancaman pidana yang lebih berat terhadap anggota geng motor yang melakukan tindak pidana secara bersama-sama.

\section{F. Rekomendasi}


1. Agar keresahan masyarakat akibat maraknya kejahatan yang dilakukan oleh geng motor dapat diatasai, konsepsi norma pemberatan pidana terhadap pelaku tindak pidana yang berasal dari geng motor, harus dilakukan melalui revisi atau perubahan/penambahan ketentuan pasal-pasal pidana terkait seperti pasal pencurian, pencurian dengan kekerasan, pemerkosaan atau pasal pembunuhan di dalam KUHP yang berlaku saat ini, dengan ayat yang menyatakan bahawa "apabila tindak pidana dalam pasal ini dilakukan oleh geng motor, maka pidana terhadap masing-masing pelaku ditambah 1/3 (satu per tiga)". Namun demikian, upaya hukum tersebut haruslah didahului dengan upaya pencegahan yang bersifat non hukum, antara lain berupa kerjasama lintas sektor untuk mendeteksi secara dini keberadaan geng motor, dan mengatasi masalah-masalah sosial yang menyebabkan timbulnya kenakalan remaja sebagai embrio dari kejahatan serius yang dilakukan oleh geng motor.

2. Agar konsepsi pemberatan pidana terhadap pelaku pidana geng motor, dapat diwujudkan menjadi normayang nyata, maka revisi ketentuan $\mathrm{KL}^{\mathrm{rm}}$ ' 'ruslah segera dilakukan, terutama menyangkut ketentuan yang menє entang perbuatan pidana yang dilakukan oleh geng motor.

\section{G. Daftar Pustaka}

Mochtar Kusumaatmadja, Hubungan Antara Hukum Dengan Masyarakat: Landasan Pikiran, Pola dan Mekanisme Pelaksanaan Pembaharuan Hukum, BPHN-LIPI, Jakarta, 1976

Mardjono Reksodiputro, Hak Asasi Manusia Dalam Sistem Peradilan Pidana, Kumpulan Karangan Buku Ketiga, Pusat Pelayanan Keadulan dan Pengabdian Hukum (d/h Lembaga Kriminologi), Universitas Indonesia, Jakarta, 2007

Sudarto, Kapita Selekta Hukum Pidana, Alumni, Bandung, 1981

Muladi, Kapita Selekta Sistem Peradilan Pidana, BP. Universitas Diponegoro, Semarang, 2002

Siswantoro Sunarso, Siswantoro Sunarso. Penegakan Hukum Psikotropika Dalam Kajian Sosiologi Hukum, Rajawali Pers, Jakarta, 2004

Muladi dan Barda Nawawi Arief, Teori-teori dan Kebijakan Pidana, Cet. Ketiga, Alumni, Bandung, 2005

Trias Palupi Kurnianingrum, "Geng Motor dari Sisi Penegakan Hukum", Jurnal Info Singkat Hukum, Vol. IV, No. 08/II/P3DI/April/2012.

Jurnal Ilmu Komunikasi, Vol. 1, No.2, Oktober 2011, ISSN: 2088-981X. 